\title{
PENERAPAN STRATEGI 7T BISNIS RITEL DALAM E-COMMERCE (ON-LINE SHOP) OLEH SWALAYAN GOLDEN SEBAGAI MEDIA PEMASARAN
}

\author{
Ema Nurzainul Hakimah \\ Fakultas Ekonomi, Universitas Nusantara PGRI - Kediri \\ ema_hakimah@yahoo.com \\ Basthoumi Muslih \\ Fakultas Ekonomi, Universitas Nusantara PGRI - Kediri \\ tom_blue_13@yahoo.com
}

\begin{abstract}
Abstrak
Penelitian ini merupakan penelitian lanjutan oleh Ema Nurzainul Hakimah (2015) dengan judul Menciptakan Kepuasan dan Loyalitas Pelanggan Berbasis Manajemen Pemasaran Retail Studi pada Pedagang Retail Anggota UMKM Kota Kediri. Pembedanya yaitu penerapan strategi merchandising bisnis ritel dalam e-commerce (on-line shop/olshop) oleh swalayan Golden sebagai media pemasaran dan mendeskripsikan respon konsumen atas layanan olshop swalayan pertama yang mampu bersaing dengan peritel modern besar di Kota Kediri yaitu Golden. Penelitian ini adalah penelitian deskriptif menggunakan pendekatan kuantitatif, dimana menjelaskan gambaran masing-masing variable penelitian strategi $7 \mathrm{~T}$ dalam olshop terhadap respon konsumen. Penelitian ini menggunakan teknik pengambilan sampel purposive sampling, dengan metode pengumpulan data menggunakan kuesioner sebagai data primer dan diolah menggunakan SPSS 23 untuk mengetahui respon konsumen dalam strategi 7T serta metode CRI (Customer Response Index) untuk mengetahui sejauh mana respon konsumen atas layanan olshop swalayan Golden Kediri. Hasil data kuesioner terhadap strategi merchandising dan layanan olshop Golden Swalayan, dapat ditarik kesimpulan bahwa kinerja dari strategi 7T merchandising yang diberikan oleh Golden Swalayan Kota Kediri dengan adanya olshop telah melebihi nilai rata-rata harapan konsumen. Hasil CRI di tiap tahap respon dalam penelitian ini, menunjukkan bahwa semua nilai tahap respon berada hampir mencapai $100 \%$. Hal ini dapat disimpulkan bahwa layanan olshop Golden Swalayan memberikan respon yang positif yaitu mendapatkan kesadaran konsumennya sehingga tertarik melakukan pembelian.
\end{abstract}

Kata kunci: $\quad$ merchandising, strategi 7T bisnis ritel, on-line shop semangat kerja karyawan.

\section{PENDAHULUAN}

\section{Latar Belakang}

Perubahan kondisi pasar dan kemajuan teknologi menuntut para pelaku bisnis/peritel selalu berinovasi untuk merebut dan mengembangkan pangsa pasar di dalam negeri maupun luar negeri. Keunggulan bersaing dalam bisnis bisa dicapai dengan pengelolaan merchandise yang baik, yaitu salah satunya menggunakan strategi 7T.

Menurut Ma'ruf(dalam Sopiah, 2008:141), merchandising adalah kegiatan pengadaan barang-barang yang sesuai dengan bisnis yang dijalani toko untuk disediakan dengan jumlah, 
waktu, dan harga yang sesuai untuk mencapai sasaran toko atau perusahaan ritel.

Merchandising merupakan salah satu bidang yang berperan menentukan keunggulan bersaing dari peritel. Merchandising berasal dari kata merchandise. Merchandise artinya barang yang diperdagangkan. Dengan demikian, Merchandising bisa didefinisikan sebagai seni dan ilmu pengelolaan merchandise sehingga dalam distribusi merchandise tersebut tercapai 7T, yaitu: produk yang Tepat, waktu yang Tepat, tempat yang Tepat, harga yang Tepat, kuantitas yang Tepat, kualitas yang Tepat, dijual dengan cara yang Tepat. -

Bisnis Ritel atau eceran kini semakin berkembang seiring dengan kemajuan teknologi informasi. Perkembangan ini tentu saja harus disesuaikan dengan kesiapan sumber daya manusia yang terlibat dalam pengelolaan entitas bisnis ritel, baik owner maupun para pegawainya. Dalam hal ini maka diperlukan penggunaan media e-commerce sebagai upaya untuk menjangkau pangsa pasar yang lebih luas. Bila masih mengelola bis̄nis ritel secara tradisional maka lambat laun akan ditinggalkan para pelanggan. Kecenderungan konsumen saat ini dalam mengkonsumsi ataupun membeli berbagai macam produk lebih mudah menggunakan adanya katalog-katalog produk dan informasi berbasis on-line dengan hanya mengakses internet. Pergeseran budaya membeli masyarakat dari membeli produk langsung di toko beralih ke aplikasi-aplikasi toko on-line (on-line shop) dalam browser maupun smartphone saat ini, dengan penawaran-penawaran produk yang dikemas lebih menarik dibandingkan toko/swalayan yang tidak menggunakan layanan olshop. Sebagaimana hasil penelitian yang dikemukakan oleh purba (2014) bahwa variasi pembelian secara impulsif (impulse buying) pada diri seorang konsumen dipengaruhi secara tidak langsung oleh online store beliefs dan secara langsung oleh browsing, sehingga browsing mempunyai peranan penting dalam mempengaruhi konsumen untuk melakukan impulse buying.

Melihat observasi awal di lapangan, swalayan Golden Kediri merupakan swalayan yang telah berdiri lama dan masih tetap bertahan di antara semakin menjamurnya swalayanswalayan lain yang lebih besar. Maka peneliti tertarik untuk melanjutkan penelitian ini dan mengangkat judul "Penerapan strategi 7T (produk yang Tepat, waktu yang Tepat, tempat yang Tepat, harga yang Tepat, kuantitas yang Tepat, kualitas yang Tepat, dijual dengan cara yang Tepat) bisnis ritel dalam e-commerce (on-line shop) oleh Swalayan Golden sebagai Media Pemasaran”.

\section{Identifikasi Masalah}

1. Pergeseran budaya membeli masyarakat dari membeli barang di tempat menjadi membeli barang melalui media olshop

2. Strategi merchandising $7 \mathrm{~T}$ menjadi salah satu strategi yang perlu diperhatikan pelaku bisnis ritel.

\section{Tujuan Penelitian}

1. Untuk mendeskripsikan penggunaan strategi 7T (produk yang Tepat, waktu yang Tepat, tempat yang Tepat, harga yang Tepat, kuantitas yang Tepat, kualitas yang Tepat, dijual dengan cara yang Tepat) bisnis ritel dalam e-commerce (on-line shop) oleh swalayan Golden sebagai media pemasaran

2. Mendeskripsikan respon konsumen atas layanan olshop swalayan Golden Kediri. 


\section{Manfaat Penelitian}

Bagi peneliti

a. Memberikan peningkatan pengetahuan yang lebih dalam penerapan strategi merchandising bisnis ritel

b. Menjadikan penelitian ini sebagai referensi untuk penelitian selanjutnya.

Bagi instansi

a. Sebagai informasi mengenai harapan konsumennya

b. Sebagai acuan pengambilan keputusan mengenai strategi merchandising dalam pemasaran produk bisnis ritel.

\section{TINJAUAN PUSTAKA}

\section{Strategi 7T Dalam Manajemen Ritel}

Menurut Ma'ruf (2005:135), merchandising adalah kegiatan pengadaan barangbarang yang sesuai dengan bisnis yang dijalani toko untuk disediakan dengan jumlah, waktu, dan harga yang sesuai untuk mencapai sasaran toko atau perusahaan ritel.

Menurut Sopiah (2008:141), merchandising adalah seni dan ilmu pengelolaan merchandise sehingga dalam distribusi merchandise tersebut tercapai 7T, yaitu: produk yang tepat, waktu yang tepat, tempat yang tepat, harga yang tepat, kuantitas yang tepat, kualitas yang tepat dan dijual dengan cara yang tepat.

Menurut Sopiah (2008:141-142) hal-hal yang perlu menjadi perhatian dalam merchandise antara lain:

1. Melakukan pesanan dan menerima kiriman pesanan sebisa mungkinsecara mudah, akurat, dan memuaskan.

2. Meminimalkan jurang waktu antara saat pesanan dan saat menerima barang serta mengkoordinasikan pengiriman barang dari berbagai pemasok yang berbeda. Memiliki cukup persediaan untuk memenuhi permintaan konsumen, tanpa harus menyimpan persediaan berlebihan.

3. Dapat segera memenuhi permintaan konsumen secara efisien.

4. Menerima barang yang dikeluhkan pembeli dan meminimalisir produk- produk yang rusak.

Merchandising merupakan salah satu bidang yang berperan menentukan keunggulan bersaing dari peritel. Dalam distribusi merchandise tersebut tercapai 7T, yaitu:

1. Produk yang Tepat.

2. Waktu yang Tepat.

3. Tempat yang Tepat.

4. Harga yang Tepat.

5. Kuantitas yang Tepat.

6. Kualitas yang Tepat.

7. Dijual dengan cara yang Tepat. 
Menurut Taufiq (2005:33), para pelanggan selalu berharap menemukan apa yang mereka cari di setiap toko. Jika pilihan A tidak ada, mungkin mereka juga akan membeli barang lain yang tadinya tidak direncanakan. Kebutuhan dan keinginan pelanggan sangat beragam, dan toko diharapkan dapat memenuhinya. Untuk bisa memuaskan harapanharapan diatas, fungsi operasional setiap toko harus saling terkoordinasi secara rapi. Apakah itu fungsi pembelian barang, pengelolaan gudang, keuangan, operasi toko, dan lain-lain. Meskipun semua penting dan harus berjalan dengan baik, kita dapat menyebutkan bahwa fungsi pengelolaan barang dagangan (merchandising) merupakan fungsi yang harus kita beri prioritas. Bagaimanapun efektif dan efisiennya bagian lain, bila urusan barang dagangan ini salah, maka hampir dapat dipastikan sukses akan sulit diraih.

\section{E-Commerce Untuk On-Line Shop}

Menurut Baum (dalam Purbo, 2000:2), E-commerce merupakan satu set dinamis teknologi, aplikasi, dan proses bisnis yang menghubungkan perusahaan, konsumen, dan komunitas tertentu melalui transaksi elektronik dan perdagangan barang, pelayanan dan infomasi yang dilakukan secara elektronik.

Definisi E-Commerce menurut Laudon dan Laudon (1998), E-Commerce adalah suatu proses membeli dan menjual produk-produk secara elektronik oleh konsumen dan dari perusahaan ke perusahaan dengan komputer sebagai perantara transaksi bisnis.

Dapat disimpulkan bahwa e-commerce adalah suatu kegiatan pemasaran secara luas yang meliputi proses pembelian, penjualan, pelayanan dan pengembangan lainnya dengan memanfaatkan media internet sebagai alat komunikasi efektif antara penjual dan pembeli sehingga diharapkan aksesnya dapat dilakukan dengan mudah serta real time-based.

Manfaat yang dapat diperoleh dari e-commerce bagi organisasi menurut Suyanto (2003) adalah :

1. Memperluas market place hingga ke pasar nasional dan international.

2. Menurunkan biaya pembuatan, pemrosesan, pendistribusian, penyimpanan dan pencarian informasi yang menggunakan kertas.

3. Memungkinkan pengurangan inventory dan overhead dengan menyederhanakan supply chain dan management tipe "pull".

4. Mengurangi waktu antara outlay modal dan penerimaan produk dan jasa.

5. Mendukung upaya-upaya business process reengineering.

6. Memperkecil biaya telekomunikasi-internet lebih murah dibanding VAN.

7. Akses informasi lebih cepat.

Selain mempunyai manfaat bagi perusahaan, menurut Suyanto (2003) e-commerce juga mempunyai manfaat bagi konsumen, yaitu:

1. Memungkinkan pelanggan untuk berbelanja atau melakukan transaksi lain selama 24 jam sehari sepanjang tahun dari hampir setiap lokasi dengan menggunakan fasilitas Wi-Fi.

2. Memberikan lebih banyak pilihan kepada pelanggan.

3. Pengiriman menjadi sangat cepat. 
4. Pelanggan bisa menerima informasi yang relevan secara detail dalam hitungan detik, bukan lagi hari atau minggu.

5. Memberi tempat bagi para pelanggan lain di electronic community dan bertukar pikiran serta pengalaman.

6. Memudahkan persaingan yang ada pada akhirnya akan menghasilkan diskon secara substansial.

Menurut Suyanto (2003), selain manfaat terhadap organisasi dan konseumen, e-commerce juga mempunyai manfaat bagi masyarakat, antara lain :

1. Memungkinkan orang untuk bekerja di dalam rumah dan tidak harus keluar rumah untuk berbelanja. Ini berakibat menurunkan arus kepadatan lalu lintas di jalan serta mengurangi polusi udara.

2. Memungkinkan sejumlah barang dagangan dijual dengan harga lebih rendah.

3. Memungkinkan orang di negara-negara dunia ketiga dan wilayah pedesaan untuk menikmati aneka produk dan jasa yang akan susah mereka dapatkan tanpa $e$-commerce.

\section{Temuan Penelitian Terdahulu Yang Relevan}

Ema Nurzainul Hakimah (2015), Menciptakan Kepuasan dan Loyalitas Pelanggan Berbasis Manajemen Pemasaran Retail Studi pada Pedagang Retail Anggota UMKM Kota Kediri. Dengan hasil bahwa semua kinerja strategi 7T (ketepatan produk, ketepatan waktu, ketepatan tempat, ketepatan harga, ketepatan kuantitas, ketepatan kualitas dan ketepatan pelayanan penjualan yang dilakukan oleh para pedagang ritel anggota UMKM Kota Kediri di pasar induk tradisional sudah diatas harapan konsumen. Hal ini menunjukkan bahwa para pedagang tersebut sudah mempunyai pemahaman bahwa konsumen adalah raja yang harus dilayani dengan sebaik-baiknya sehingga mereka puas dan akan menjadi pelanggan mereka sehingga pelanggan akan merekomendasikan kepada orang lain (word of mouth) dan pembelian ulang (purchase intention).

Bertha Desviani Purba dan Citra Kusuma Dewi (2014), Pengaruh Online Store Beliefs melalui Browsing terhadap Impulse Buying pada Toko Online (Studi pada Lazada.co.id). Dengan hasil bahwa variasi pembelian secara impulsif (impulse buying) pada diri seorang konsumen dipengaruhi secara tidak langsung oleh online store beliefs dan secara langsung oleh browsing, sehingga browsing mempunyai peranan penting dalam mempengaruhi konsumen untuk melakukan impulse buying.

\section{METODE PENELITIAN}

\section{Pendekatan dan Teknik Penelitian}

Penelitian ini adalah penelitian deskriptif menggunakan pendekatan kuantitatif, untuk mendeskripsikan 7T dilakukan dengan teknik survey.

\section{Jenis dan Sumber Data}

Jenis data yang digunakan adalah data primer, yang diperoleh memalui kuesioner dan diolah menggunakan SPSS 23 untuk mengetahui respon konsumen.

\section{Subyek dan Obyek Penelitian}


Subyek penelitian ini adalah Golden Swalayan Kediri, dengan obyek penelitian adalah konsumen yang melakukan belanja secara online.

\section{Populasi dan Sampel}

Populasi dalam penelitian ini adalah seluruh konsumen Golden Swalayan Kediri, sedangkan sampel sejumlah 200 konsumen yang dipilih secara purposive sampling dengan kriteria :

1. Pernah berbelanja secara online

2. Berusia $25-35$ tahun

3. Memiliki smartphone dan dapat mengakses internet

\section{Teknik Pengumpulan data}

Untuk pengumpulan data kuesioner dilakukan secara online dengan menggunakan Google Drive, dimana responden diarahkan mengakses link kuesioner http://goo.gl/ forms/0IE10EEyqDIzRbH03. Link tersebut dikirimkan ke nomor hp pribadi responden, yang mana nomor hp pribadi (contact person) responden diperoleh dari database biodata konsumen Swalayan Golden Kediri.

\section{Pengujian Instrumen}

Sebelum dianalisis lebih lanjut instrumen penelitian harus dilakukan uji instrument. Adapun hasil uji validitas dan reliabilitas instrument penelitian adalah sebagai berikut:

Tabel 1 Hasil Uji Validitias

\begin{tabular}{|ll|r|}
\hline \multicolumn{2}{|c|}{ Correlations } & Strategi 7T \\
\hline x1 & Pearson Correlation & $.657^{* *}$ \\
& Sig. (2-tailed) & .000 \\
& N & 200 \\
\hline x2 & Pearson Correlation & $.632^{* *}$ \\
& Sig. (2-tailed) & .000 \\
& N & 200 \\
\hline x3 & Pearson Correlation & $.717^{* *}$ \\
& Sig. (2-tailed) & .000 \\
& N & 200 \\
\hline x4 & Pearson Correlation & $.698^{* *}$ \\
& Sig. (2-tailed) & .000 \\
& N & 200 \\
\hline
\end{tabular}




\begin{tabular}{|ll|r|}
\hline & & Strategi 7T \\
\hline x5 & Pearson Correlation & $.591^{* *}$ \\
& Sig. (2-tailed) & .000 \\
& N & 200 \\
\hline x6 & Pearson Correlation & $.475^{* *}$ \\
& Sig. (2-tailed) & .000 \\
& N & 200 \\
\hline x7 & Pearson Correlation & $.535^{* *}$ \\
& Sig. (2-tailed) & .000 \\
& N & 200 \\
\hline
\end{tabular}

**. Correlation is significant at the 0.01 level

(2-tailed).

Dari hasil analisis diatas didapat nilai skor item dengan skor total. Nilai tersebut kemudian dibandingkan dengan dengan nilai r-tabel, jika hasil korelasi (pearson correlation) $>$ r-tabel dikatakan valid dan sebaliknya jika jika hasil korelasi (pearson correlation) $<$ r-tabel dikatakan tidak valid.

a. R-tabel dicari pada tingkat signifikansi 5\% dan $n=200$ didapatkan r-tabel sebesar 0,139.

b. Maka dapat disimpulkan bahwa semua item telah valid karena memiliki pearson correlation (r-hitung) yang lebih besar dari r-tabel.

\section{Tabel 2 Hasil Uji Reliabilitas}

\section{Reliability Statistics}

\begin{tabular}{|r|r|}
\hline $\begin{array}{c}\text { Cronbach's } \\
\text { Alpha }\end{array}$ & N of Items \\
\hline .726 & 7 \\
\hline
\end{tabular}

Kriteria yang digunakan adalah Menurut Nunally dalam Imam Ghozali dikatakan reliabel jika nilai cronbach's alpha lebih besar dari 0,6. Tabel di atas menunjukkan bahwa besarnya koefisien alpha cronbach lebih besar dari 0.6, dengan demikian kuisioner yang disajikan kepada responden dinyatakan reliabel.

\section{Teknik Analisa Data}

Dalam mengukur efektifitas merchandising pada penelitian ini adalah dengan menggunakan metode CRI (Customer Response Index). Metode yang digunakan adalah metode survey. CRI merupakan hasil perkalian antara awareness (kesadaran), comprehend (pemahaman konsumen), interest (ketertarikan), intentions (maksud untuk membeli), dan action (bertindak membeli). Menurut Durianto, Sugiarto, Widjaja, dan Supraktikno (2003, p. 48), CRI menampilkan proses pembelian yang berawal dari munculnya awareness (kesadaran) konsumen, yang pada akhirnya mampu mengarahkan konsumen pada suatu 
aktivitas action (bertindak membeli). CRI sendiri dapat digunakan sebagai salah satu alat untuk mengukur efektivitas iklan, karena komunikasi pemasaran sangat berperan penting dalam membangkitkan iklan yang efektif. Indikator dari merchandising $7 \mathrm{~T}$ yaitu produk yang Tepat, waktu yang Tepat, tempat yang Tepat, harga yang Tepat, kuantitas yang Tepat, kualitas yang Tepat, dijual dengan cara yang Tepat. Sedangkan indicator CRI yaitu awareness (kesadaran), comprehend (pemahaman konsumen), interest (ketertarikan), intentions (maksud untuk membeli), dan action (bertindak membeli).

Dalam Hierarchy of Effects, tahapan satu dengan tahapan lain memiliki ikatan yang kuat, dimana tahapan awal mempengaruhi tahapan selanjutnya, dan seterusnya hingga tahapan akhir (Kotler \& Keller, 2009:516). Hal ini pula yang terjadi dalam CRI. Selain itu, CRI merupakan satu-satunya metode pengukuran efektivitas iklan yang tidak hanya memiliki tahap awareness saja, tetapi juga memposisikan tahap awareness sebagai tahap awal dalam mengukur efektivitas iklan. Apabila suatu iklan tidak dapat melewati tahap awareness maka tahap lain tidak akan tercapai. Berikut adalah model CRI:

\section{Gambar 1 Model CRI (Customer Response Index)}

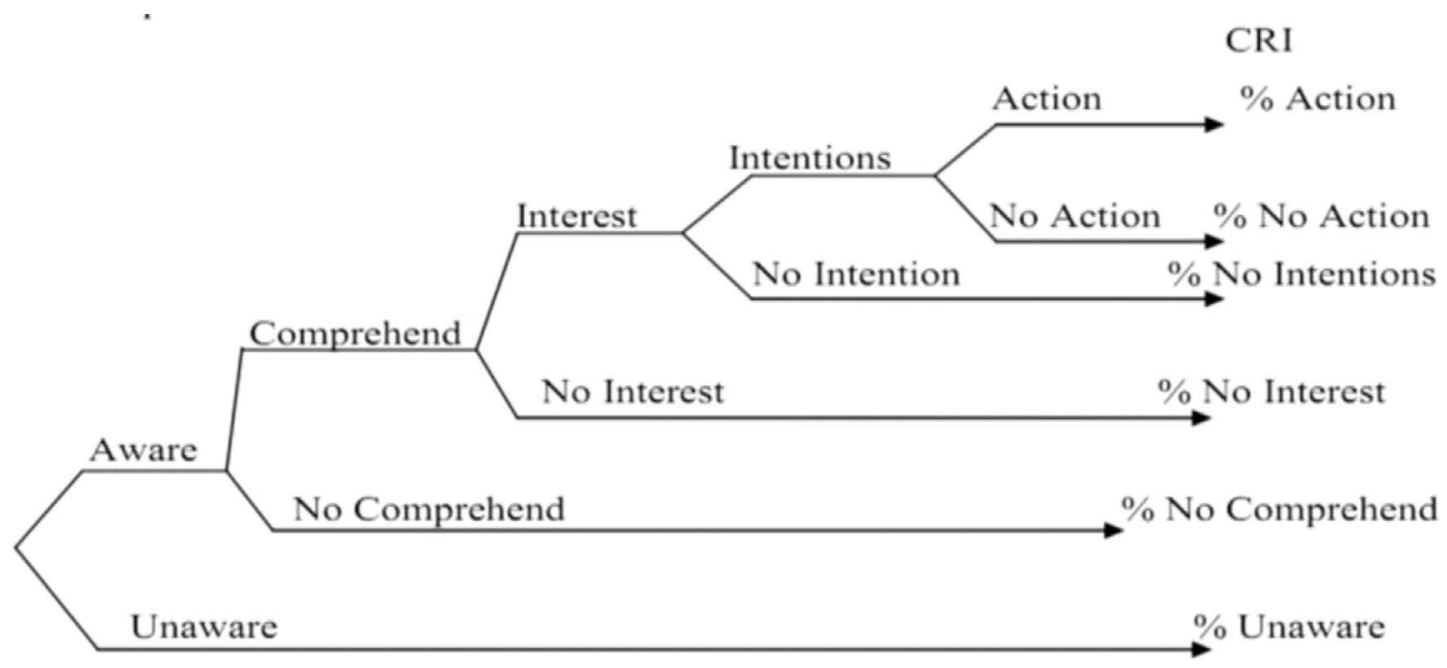

Rumus penghitungan CRI sebagai berikut (Utama, Andadari, dan Matrutty, 2009):

1. Unawareness

2. No Comprehend $=$ Awareness $x$ No Comprehend

3. No Interest $=$ Awareness $x$ Comprehend $x$ No Interest

4. No Intentions $=$ Awareness $x$ Comprehend $x$ Interest $x$ No Intentions

5. No Action $=$ Awareness $x$ Comprehend $x$ Interest $x$ Intentions $x$ No Action

6. Action $=$ Awareness $x$ Comprehend $x$ Interest $x$ Intentions $x$ Action

Berdasarkan rumus penghitungan CRI di atas, tahap pertama ialah tahap unawareness atau tidak sadar terhadap keberadaan suatu iklan. Tahap selanjutnya ialah tingkat no comprehend (tidak paham) dimana jumlahnya didapat dari perkalian persentase audience yang awareness (sadar) dan no comprehend (tidak paham) terhadap iklan. Tahap berikutnya ialah tahap no interest (tidak tertarik) berupa perkalian antara persentase audience yang awareness (sadar) dengan yang comprehend (paham) dan no interest (tidak tertarik). 
Selanjutnya, tahap no intentions (tidak berminat) dimana merupakan hasil perkalian antara persentase audience yang awareness (sadar), comprehend (paham) dengan interest (tertarik) dan yang no intentions (tidak berminat). Tahap berikutnya ialah tahap no action dimana merupakan hasil perkalian antara persentase audience yang awareness (sadar), comprehend (paham), interest (tertarik), intentions (minat) dan no action (tidak bertindak). Tahap terakhir ialah tahap action (tindakan) diperoleh melalui hasil perkalian antara persentase audience yang awareness (sadar), comprehend (paham), interest (tertarik), intentions (minat), dan action (tindakan). Hasil akhir CRI berbentuk persentase jumlah audience yang telah melewati tahapan-tahapan dalam CRI, mulai dari awareness hingga action.

\section{HASIL DAN PEMBAHASAN}

\section{Strategi 7 T Golden Swalayan Kota Kediri}

Menggunakan software SPSS Versi 23, maka diperoleh nilai rata-rata kinerja yang lebih tinggi dari harapan. Berikut tabel skor jawaban masing-masing atribut kinerja dan tingkat harapan dari kinerja strategi 7T merchandising dari Golden Swalayan Kota Kediri:

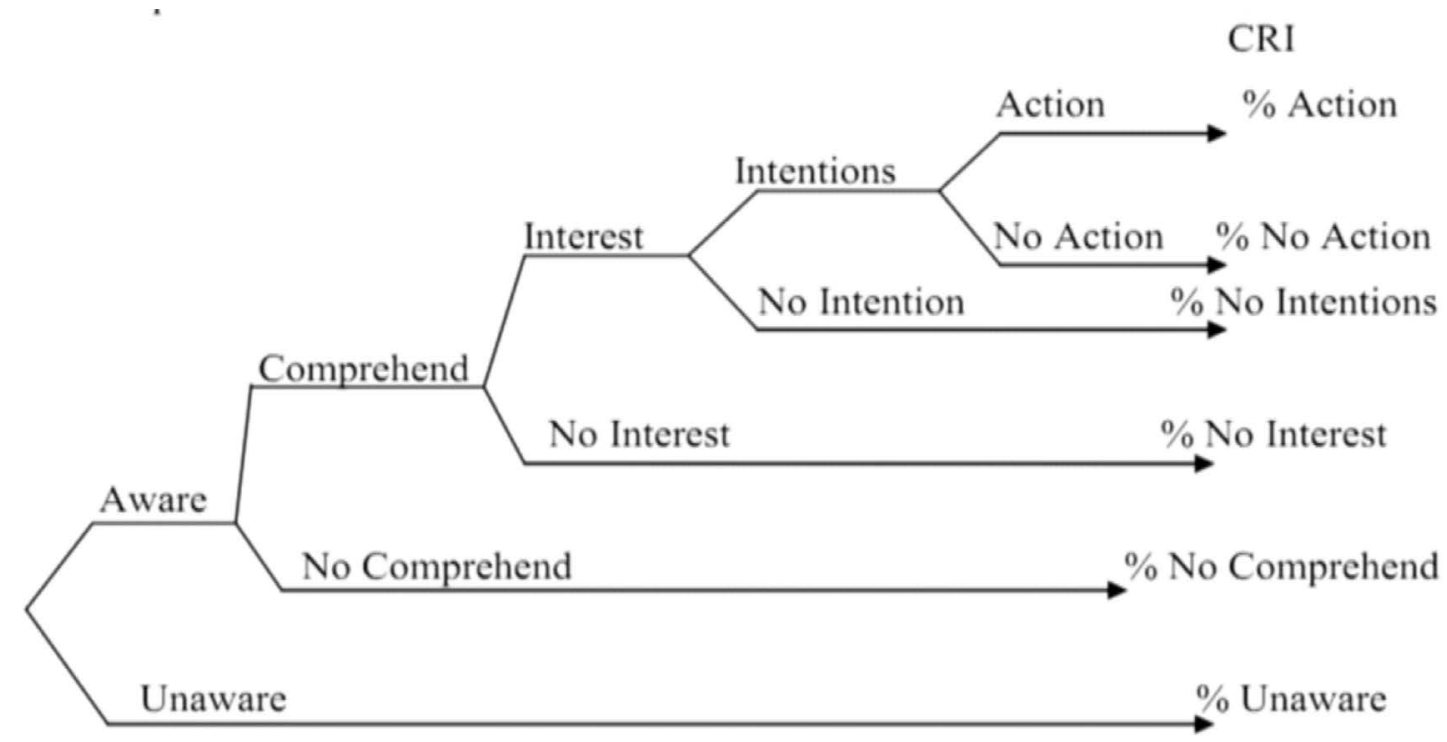

Sumber: data primer diolah 2016

Berdasarkan hasil perhitungan diatas diperoleh bahwa nilai rata-rata kinerja dari strategi 7T merchandising yang diberikan oleh Golden Swalayan Kota Kediri dengan adanya olshop sudah melebihi nilai rata-rata harapan konsumen, yaitu untuk ketepatan produk 4.4152>4.3636; ketepatan waktu 4.2450 >4.1270; ketepatan tempat 4.3420>4.2320; ketepatan kuantitas 4.3210 $>4.1938$; ketepatan harga 4.5562 $>4.5472$; ketepatan pelayanan/ cara penjualan 4.4367>4.3385; dan ketepatan kualitas 4.4557>4.3477.

\section{Customer Response Index (CRI)}

Berdasarkan hasil data yang disebar pada 100 responden, hasil CRI yang didapat ialah sebagai berikut : 


\section{Gambar 2 Customer Response Index (CRI) konsumen terhadap layanan olshop Golden Swalayan}

\begin{tabular}{|l|r|r|r|r|r|r|}
\hline \multirow{2}{*}{} & \multicolumn{2}{|c|}{$\mathrm{N}$} & \multicolumn{2}{c|}{ Mean } & \multicolumn{2}{c|}{ Std. Deviation } \\
\cline { 2 - 7 } & \multicolumn{1}{|c|}{ Kinerja } & Harapan & \multicolumn{1}{c|}{ Kinerja } & Harapan & Kinerja & \multicolumn{1}{c|}{ Harapan } \\
\hline Ketepatan produk & 200 & 200 & 4.4152 & 4.3636 & .47343 & .47534 \\
Ketepatan waktu & 200 & 200 & 4.2450 & 4.1270 & .43642 & .63245 \\
Ketepatan tempat & 200 & 200 & 4.3420 & 4.2320 & .58474 & .66877 \\
Ketepatan kuantitas & 200 & 200 & 4.3210 & 4.1938 & .43506 & .48573 \\
Ketepatan harga & 200 & 200 & 4.5562 & 4.5472 & .46372 & .64539 \\
Ketepatan pelayanan penjualan & 200 & 200 & 4.4367 & 4.3385 & .44784 & .62111 \\
Ketepatan kualitas & 200 & 200 & 4.4557 & 4.3477 & .45358 & .65348 \\
\hline
\end{tabular}

Sumber: data primer diolah 2016

Berdasarkan model CRI di atas, dapat dilihat hasil masing-masing persentase responden di tiap tahapan respon CRI dan nilai kelima tahapan respons tersebut di atas $50 \%$. Tahap respon awareness dimana tahap pertama, sebanyak $87 \%$ responden menyatakan sadar dengan adanya layanan olshop di Golden Swalayan, sedangkan sebanyak 13\% responden menyatakan tidak sadar (unawareness) dengan layanan olshop di Golden Swalayan. Pada tahap respon comprehend, sebanyak $93,1 \%$ responden yang paham dengan layanan olshop di Golden Swalayan, sedangkan sisanya sebanyak 6,9\% responden menyatakan tidak paham. Di tahap respon interest, sebanyak $91,4 \%$ responden yang paham menyatakan tertarik dengan apa yang ditawarkan dalam layanan olshop di Golden Swalayan, sedangkan sisanya sebanyak $8,6 \%$ responden menyatakan tidak tertarik. Di tahap intentions, sebanyak $83,8 \%$ responden yang tertarik menyatakan bahwa berminat pada apa yang ditawarkan dalam layanan olshop di Golden Swalayan, sedangkan sisanya sebesar 6,2\% responden menyatakan tidak berminat. Tahap respon terakhir ialah action, sebanyak $74,2 \%$ responden yang berminat menyatakan telah menggunakan layanan olshop di Golden Swalayan, sedangkan sisanya sebesar 25,8\% responden menyatakan tidak menggunakan layanan olshop di Golden Swalayan.

Hasil persentase tiap tahap respon tersebut diproses melalui rumus penghitungan CRI sebagai berikut (Utama, Andadari, dan Matrutty, 2009):

1. Unawareness = Persentase responden yang unawareness

$=13 \%$

2. No Comprehend = Awareness $x$ No Comprehend

$=87 \% \times 6,9 \%$

$=6 \%$

3. No Interest = Awareness $x$ Comprehend $x$ No Interest

$=87 \% \times 93,1 \% \times 8,6 \%$

$=7 \%$

4. No Intentions = Awareness $x$ Comprehend $x$ Interest $x$ No Intentions

$=87 \% \times 93,1 \% \times 91,4 \% \times 16,2 \%$

$=12 \%$

5. No Action = Awareness $x$ Comprehend $x$ Interest $x$ Intentions $x$ No Action

$=87 \% \times 93,1 \% \times 91,4 \% \times 83,8 \% \times 25,8 \%$

$=16 \%$

6. Action

$=$ Awareness $x$ Comprehend $x$ Interest $x$ Intentions $x$ Action

$=87 \% \times 93,1 \% \times 91,4 \% \times 83,8 \% \times 74,2 \%$

$=46 \%$ 
Berdasarkan hierarchy of effects yang ada, terlihat bahwa iklan yang efektif adalah iklan yang dapat membuat audience sebagai konsumen melewati beberapa tahapan respon, mulai dari awareness (kesadaran) hingga tindakan nyata. Berdasarkan pada hasil keseluruhan tahap respons CRI yang didapat dari penelitian ini, terlihat adanya respons yang cukup tinggi di keseluruhan tahap respon CRI, dimulai dari awareness $(87 \%)$, comprehend $(93,1 \%)$, interest (91,4\%), intentions (83,8\%), dan action (46\%).

Melalui proses penghitungan rumus CRI, di tahap respon comprehend hingga action mengalami pengurangan. Hal ini disebabkan pada adanya responden yang no comprehend sebesar $6 \%$, no interest sebesar $7 \%$, no intentions sebesar $12 \%$, dan no action sebesar $16 \%$. Hasil akhir CRI yang didapat ialah pada tahap action yaitu sebesar $46 \%$. Nilai tahap action sebesar $46 \%$ menunjukkan bahwa responden tersebut telah terkena efek stimulus respon dimana efek stimulus respon yang berakhir pada tindakan yaitu pembelian.

Layanan olshop di Golden Swalayan juga tergolong efektif dalam menimbulkan efek audience-nya dimulai dari kognitif yang pada tahap respons CRI yaitu awareness (kesadaran) dan comprehend (pemahaman), afektif yang pada tahap respons CRI yaitu interest (tertarik) dan intentions (berminat), konatif (individu melakukan sesuatu menurut anjuran iklan) yang pada tahap respons CRI yaitu action (tindakan).

\section{Pembahasan}

Berdasarkan analisis yang dilakukan dapat dinyatakan bahwa nilai rata-rata kinerja dari strategi 7T merchandising yang diberikan oleh Golden Swalayan Kota Kediri dengan adanya olshop sudah melebihi nilai rata-rata harapan konsumen. Hal ini dapat dibuktikan secara langsung bahwa Golden tetap menjadi tempat belanja pilihan masyarakat Kediri dan sekitarnya, baik yang melakukan pembelian secara langsung maupun secara online atau melalui media sosial (facebook, instagram, dan twitter).

Adapun hasil masing-masing persentase responden di tiap tahapan respon CRI dan nilai kelima tahapan respons tersebut di atas 50\%. Berdasarkan pada hasil keseluruhan tahap respons CRI yang didapat dari penelitian ini, terlihat adanya respons yang cukup tinggi di keseluruhan tahap respon CRI, dimulai dari awareness (87\%), comprehend (93,1\%), interest (91,4\%), intentions (83,8\%), dan action (46\%).

Nilai tahap action sebesar $46 \%$ menunjukkan bahwa responden/ konsumen tersebut telah terkena efek stimulus respon dimana efek stimulus respon dari media pemasaran online dan sosial medaia yang digunakan oleh Golden Swalayan berakhir pada tindakan yaitu pembelian atau belanja di Golden Swalayan Kediri.

\section{SIMPULAN DAN SARAN}

Berdasarkan temuan data kuesioner terhadap strategi merchandising dan layanan olshop Golden Swalayan, maka dapat ditarik kesimpulan dari penelitian ini bahwa kinerja dari strategi 7T merchandising yang diberikan oleh Golden Swalayan Kota Kediri dengan adanya olshop telah melebihi nilai rata-rata harapan konsumen. Hasil CRI di tiap tahap respon dalam penelitian ini, menunjukkan bahwa semua nilai tahap respon berada hampir mencapai 100\%. Hal ini dapat disimpulkan bahwa layanan olshop Golden Swalayan memberikan respon yang positif yaitu mendapatkan kesadaran konsumennya sehingga tertarik melakukan pembelian. 
Untuk menghadapi masyarakat dan juga pelanggannya, Golden Swalayan perlu melakukan sesuatu yang spesifik terkait dengan online shopnya, yaitu membuatkan system pembelian online shop secara sistematis dan menarik dengan informasi yang selalu up to date, bagi para pecintanya di berbagai media sosial (fecebook, instagram dan twitter). System penjualan dan pelayanan online shop yang selama ini ada sangat perlu untuk diperhatikan dan dikelola dengan maksimal, sehingga dapat mengikuti permintaan dan harapan konsumen dan pelanggannya yang dewasa ini memiliki mobilitas yang tinggi. Dengan demikian Golden Swalayan akan tetap menjadi Swalayan pilihan dan legendaris bagi masyarakat Kediri dan sekitarnya

\section{DAFTAR PUSTAKA}

Arikunto, Suharsimi. 2002. Prosedur Penelitian: Suatu Pendekatan Praktek. Edisi Revisi V. Jakarta: PT Rineka Cipta.

Arikunto, Suharsimi. 2006. Prosedur Penelitian: Suatu Pendekatan Praktek. Edisi Revisi VI. Jakarta: PT. Rineka Cipta.

Kotler, P. \& Keller, K. L. (2009). Marketing Management 13th ed. New Jersey: Pearson Education, Inc.

Kotler, P. \& Armstrong, G. 2001. Prinsip-prinsip Pemasaran Jilid 1. Terjemahan Damos Sihombing. Jakarta: Erlangga.

Kotler, P \& Susanto, A. B. 2002. Manajemen Pemasaran di Indonesia. Buku 2. Jakarta: Salemba Empat.

Ma'ruf, Hendri. (2005). Pemasaran Ritel. Jakarta: PT. Gramedia Pustaka Utama.

Moleong, Lexy J.Dr. 2002. Metode Penelitian Kualitatif. Bandung: Remaja.

Nazir, M. 1985. Metode Penelitian. Jakarta: Ghalia Indonesia.

Purbo, Onno W. 2001. Mengenal eCommerce. Jakarta: PT. Elex Media Komputindo.

Rangkuti, F. 1997. Riset Pemasaran. Jakarta: PT Gramedia Pustaka Utama.

Riduan. 2010. Dasar-dasar Statistik. Bandung: Alfabeta.

Setiadi, N. 2003. Perilaku Konsumen. Jakarta: Studia Press.

Sopiah dan Syihabudhin. 2008. Manajemen Bisnis Ritel. Edisi 1. Yogyakarta: Andi Offset.

Sugiyono. 2004. Metode Penelitian Bisnis. Bandung: Alfabeta.

Sugiyono. 2005. Metode Penelitian Bisnis. Bandung: CV. Alfabeta.

Sumarwan, U. 2004. Perilaku Konsumen. Bogor Selatan: Ghalia Indonesia.

Taufiq, A. 2005. Manajemen Ritel. Jakarta: Penerbit PPM.

Tjiptono, F. 2005. Brand Management \& Strategy. Yogyakarta: Andi

Umar, H. 2003. Riset Pemasaran dan Perilaku Konsumen. Jakarta: PT. Gramedia Pustaka Utama

Utama, S.S., Andadari, R.K., \& Matrutty, E.S. (2009). Efektivitas Iklan Televisi Partai Gerindra berdasarkan Metode Customer Response Index (CRI) DI Salatiga. Jurnal Ekonomi dan Bisnis vol. XV no.1 Maret 2009, p.89-102. 